Vol. 11 (3): 473-476 (2021)

\title{
THE DISTRIBUTION OF NATURAL RADIONUCLIDE CONCENTRATION IN SOIL IN TIRANA URBAN AREA
}

\author{
E. Gjeçi ${ }^{1 *}$, P. Dhoqina ${ }^{1}$ \\ ${ }^{1 *}$ University of Tirana, Faculty of Natural Sciences, Department of Physics, Blvd. Zogu I, 1001 Tirana, Albania; \\ *Corresponding Author Eranda Gjeçi, e-mail: eranda.lika@fshn.edu.al;
}

Received March 2021; Accepted April 2021; Published May 2021;

DOI: https://doi.org/10.31407/ijees11.315

\begin{abstract}
The data reported in this manuscript are the results of a systematic survey of natural radioactivity concentration in soils in Tirana urban area. The activity concentrations of natural radionuclides of ${ }^{40} \mathrm{~K},{ }^{226} \mathrm{Ra}\left({ }^{238} \mathrm{U}\right)$ and ${ }^{232} \mathrm{Th}$, and artificial radionuclide of ${ }^{137} \mathrm{Cs}$ in 71 soil samples were measured using a high-resolution gamma-ray spectrometry technique. The average activity concentrations of ${ }^{40} \mathrm{~K},{ }^{226} \mathrm{Ra}$ and ${ }^{232} \mathrm{Th}$ were found to be $382 \pm 113,32 \pm 12$ and $32 \pm$ $12 \mathrm{~Bq} / \mathrm{kg}$ respectively, while, the average activity concentration of ${ }^{137} \mathrm{Cs}$ was found to be $5 \pm 5 \mathrm{~Bq} / \mathrm{kg}$. These values were found to be comparable with similar studies reported in literature for different countries in the Balkans Region. Based on these data, the average annual effective dose rate was found to be $0.06 \pm 0.02 \mathrm{mSv} / \mathrm{y}$, which is comparable with the worldwide average values of $0.07 \mathrm{mSv} / \mathrm{y}$. The results show that the radioactivity level in the soil of Tirana urban area does not pose any significant risk to population.
\end{abstract}

Keywords: Natural radioactivity; Soil; HPGe gamma-ray spectrometer; Radiological hazard; Dose rate 